\title{
Soja geneticamente modificada em alimentos contendo farinha e preparados à base de farinha de trigo. Detecção e adequação à legislação de rotulagem
}

Genetically modified soybean in food containing wheat flour and wheat flour-based preparations. Detection and fitness to labeling legislation

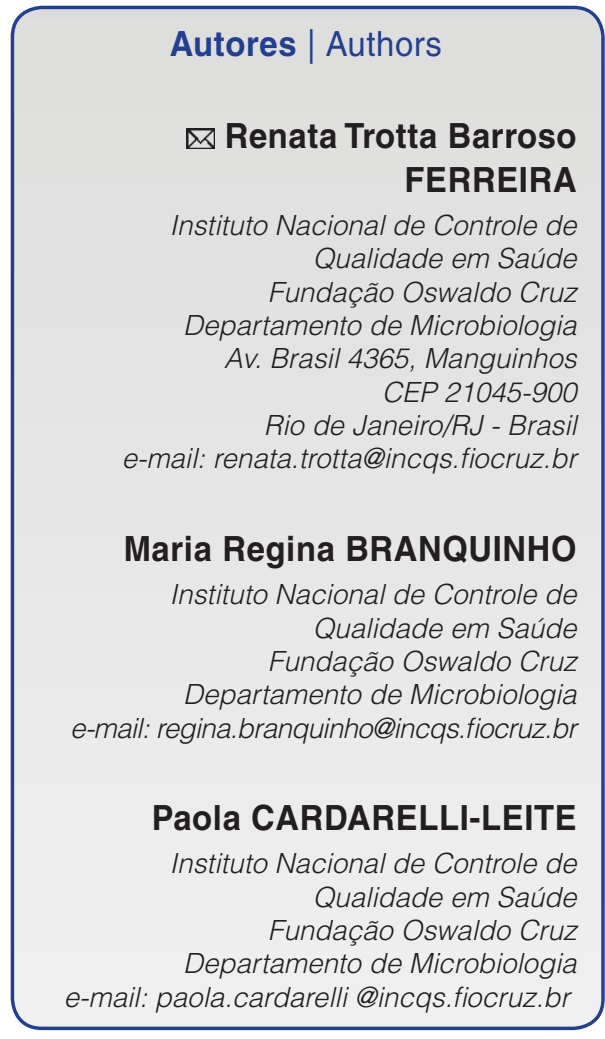

Autor Correspondente / Corresponding Author

Recebido / Received: 26/11/2008 Aprovado / Approved: 09/09/2009

\section{Resumo}

A farinha de trigo é considerada como um dos principais ingredientes utilizados no preparo dos alimentos e, portanto, presente em praticamente todas as refeições dos brasileiros.

Em 2000, o consumo per capita de farinha de trigo correspondia a $53 \mathrm{~kg}$ e estava distribuída da seguinte forma no mercado brasileiro: $47 \%$ padarias; $14 \%$ indústrias de massas; $20 \%$ consumo doméstico; $8 \%$ indústria de biscoito; $5 \%$ indústria de pães; e $6 \%$ em outros segmentos. O objetivo deste trabalho foi avaliar a presença de soja e soja Roundup Ready ${ }^{\circledR} \mathrm{em}$ amostras de farinhas de trigo e de preparados à base de farinha de trigo para a alimentação humana e verificar a adequação dos rótulos frente à legislação pela análise quantitativa por PCR em Tempo Real. O INCQS/FIOCRUZ analisou 16 amostras de farinhas de trigo de 10 marcas diferentes. Quinze (15) amostras apresentaram resultado positivo para o gene le1 da lectina, demonstrando a presença de soja nestes produtos, e doze (12) amostras apresentaram resultado positivo para o gene CP4 EPSPS, específico da soja $\mathrm{RR}^{\circledR}$, evidenciando a utilização de soja geneticamente modificada nestes produtos. Todas as amostras analisadas denominadas como preparados à base de farinha de trigo para a alimentação humana, conhecidos comercialmente como mistura para bolos, quiches, panquecas e bolinhos de chuva apresentaram resultados positivos para o gene específico da soja $\mathrm{RR}^{\circledast} \mathrm{e}$ deveriam conter no rótulo o símbolo estabelecido na Portaria n² 2658, de 22 de dezembro de 2003.

Palavras-chave: Soja geneticamente modificada; Alimentos; PCR; Trigo; Vigilância sanitária.

\section{Summary}

Wheat flour is regarded as one of the main ingredients used in food preparation and is therefore present in virtually all Brazilian meals.

In 2000, the per capita consumption of wheat flour corresponded to $53 \mathrm{~kg}$ and was distributed as follows on the Brazilian market: $47 \%$ bakeries, $14 \%$ pasta industries, $20 \%$ domestic consumption, $8 \%$ biscuit industries, $5 \%$ bread industries and $6 \%$ in other segments. The objective of this study was to evaluate the presence of soybeans and Roundup Ready ${ }^{\circledR}$ soybeans in wheat flour samples and wheat flour-based preparations for human consumption, and to verify the adequacy of the labels with respect to the legislation using Real Time PCR quantitative analysis. INCQS/FIOCRUZ analyzed 16 wheat flour samples of 10 different brands. Fifteen (15) samples showed positive results for the le 1 lectin gene, showing the presence of soybeans in these products, and twelve (12) samples showed positive results for the CP4 EPSPS gene, specific for the $\mathrm{RR}^{\circledR}$ soybean, demonstrating the use of genetically modified soybean in these products. All the analyzed samples classified as wheat flour-based food preparations for human consumption, known commercially as cake, quiche, pancake and cookie mixes, tested positive for the $\mathrm{RR}^{\circledast}$ soybean bean, and should therefore include the symbol established by Regulation No 2658 of $22^{\text {nd }}$ December, 2003 on the label.

Key words: Genetically modified soybean; Food; PCR; Wheat; Sanitary surveillance. 


\section{Introdução}

O trigo é o principal cereal produzido no mundo e, diferentemente da soja, é usado prioritariamente na alimentação humana. A praticidade do uso de produtos semiprontos e a mudança nos padrões de consumo do brasileiro têm levado várias empresas da indústria alimentícia a utilizarem o trigo como matéria-prima para elaboração de produtos prontos ou semiprontos, como bolos, biscoitos, pães, massas alimentícias secas, frescas, recheadas e instantâneas, tortas salgadas e doces, pizzas, molhos de carne, ervilha e cebola e produtos empanados, entre outros (ABITRIGO, 2006; SOARES et al., 2004). Em 2000, o consumo per capita de farinha de trigo correspondia a $53 \mathrm{~kg}$ e estava distribuído da seguinte forma no mercado: $47 \%$ em padarias; $14 \%$ em indústrias de massas; $20 \%$ no consumo doméstico; $8 \%$ em indústrias de biscoitos; $5 \%$ em indústrias de pães; e $6 \%$ em outros segmentos (INMETRO, 2005).

Por ser uma cultura predominantemente de inverno, o trigo é cultivado na região Sul, com destaque para os Estados do Paraná e do Rio Grande do Sul. Todavia, está acontecendo um processo de expansão do cultivo na direção da região central do País, em especial para o Estado de Mato Grosso do Sul. Os moinhos por sua vez, estão distribuídos por todas as regiões brasileiras, sendo que a maior capacidade de moagem está instalada na região sudeste do País (SINGER, 2006; CAMARGO et al., 2004).

O Brasil é, indiscutivelmente, um dos principais atores no cenário do agronegócio internacional (SINGER, 2006). No passado, o Brasil chegou a produzir 90\% do trigo consumido internamente. No entanto, devido a uma série de fatores, gradativamente a dependência brasileira pela importação desse grão foi aumentando, sendo que na safra 1999/00, apenas $16,5 \%$ da demanda foi suprida com a produção nacional. O reflexo dessa situação foi percebido na balança comercial: as importações de trigo (na casa de US\$ 900 milhões) foram responsáveis por quase a metade das importações do agronegócio brasileiro em 2002. A avaliação da safra agrícola 2006/2007 foi de 10 mil toneladas de consumo do trigo, sendo produzidas apenas 2 mil toneladas e importadas as 8 mil toneladas restantes (CONAB, 2006). Consequentemente, grãos nacionais estão sendo misturados aos importados da Argentina, Canadá e Estados Unidos, em proporções diversas (COSTA et al., 2008).

Embora a soja em grão não seja muito consumida no Brasil, seus subprodutos fazem parte da composição de produtos processados como, sopas desidratadas e enlatadas, biscoitos, produtos de panificação, produtos embutidos, produtos cárneos, misturas de cereais, bombons, achocolatados à base de cereais, iogurtes, sucos, cremes, óleo, rações animais, etc.
Vários trabalhos demonstram o uso de farinha de soja enzimaticamente ativa na manufatura de produtos de padaria como um melhorador da atividade reológica da massa, interferindo na formação do glúten, no aumento da capacidade de retenção do gás na massa e no enfraquecimento e extensão da massa (ARAÚJO et al., 1996; RIBOTTA, et al. 2005).

A legislação brasileira através da Instrução Normativa $n^{\circ} 08$ de 02/06/2005, permite o uso de soja em produtos de panificação, desde que a correta identificação seja realizada a fim de que o consumidor seja informado (BRASIL, 2005).

Em 2003, o Brasil regulamentou o plantio e a comercialização da soja geneticamente modificada. Instituiu pelo Decreto $n^{\circ}$ 4680, de 24 de abril de 2003, o limite de $1 \%$ para a informação no rótulo de produtos alimentícios que contenham ou sejam constituídos por Organismos Geneticamente Modificados (OGM) e criou o símbolo que deve constar nas embalagens dos produtos que se encontram nessa situação conforme a Portaria $n^{\circ}$ 2658, de 22 de dezembro de 2003 (Figura 1). Criou-se, a partir daí, uma nova situação para o Brasil e o controle da qualidade de alimentos tornou-se ponto essencial para a aplicação do Princípio da Precaução e dos direitos do consumidor à informação pela verificação do cumprimento da legislação de rotulagem, atuando no rastreamento e no controle pós-comercialização (BRASIL, 2002; 2003a; 2003b).

A rotulagem de alimentos é o principal meio de comunicação entre o produtor e o consumidor. Por isso, deve-se fazer valer que os ingredientes constituintes da composição de produtos estejam de forma clara no rótulo desses produtos (BRASIL, 2002).

O controle da qualidade de alimentos que contenham OGM necessita utilizar métodos analíticos confiáveis. A Reação em Cadeia pela Polimerase (PCR) é um método altamente específico e sensível para detectar pequenas quantidades de DNA alvo, sendo, portanto, uma ferramenta confiável tanto para identificar

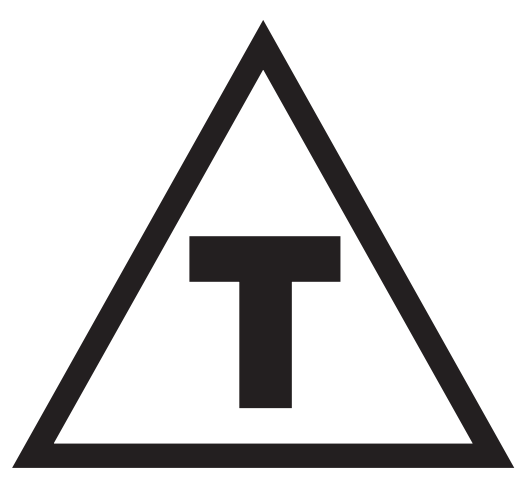

Figura 1. Símbolo que deve constar no rótulo dos alimentos que contenham OGM em sua composição (BRASIL, 2003b). 
- OGM como para avaliar a rotulagem destes alimentos (JANKIEWICZ et al., 1999).

O objetivo deste trabalho foi detectar a presença de soja e de soja Roundup Ready em amostras de farinhas de trigo e preparados à base de farinha de trigo para a alimentação humana e verificar a adequação dos rótulos frente à legislação pela análise quantitativa por PCR em Tempo Real.

\section{Material e métodos}

\subsection{Amostras}

Foram analisadas 16 amostras de "farinha de trigo" de 10 diferentes marcas e 8 amostras de produtos identificados como "preparados à base de trigo" de 7 diferentes marcas, totalizando um universo de 24 amostras coletadas no comércio das cidades do Rio de Janeiro e São Paulo.

Materiais de Referência apropriados para controle positivo e negativo fornecem a base para a validação de procedimentos analíticos e para avaliar a eficácia de métodos e desempenho de laboratórios (AHMED et al., 2002). Os Materiais de Referência Certificados (MRC) utilizados eram constituídos de farinha de soja com concentrações de $0 \%, 0,1 \%, 0,5 \%, 1 \%, 2 \%$ e $5 \%$ de soja $\mathrm{RR}^{\circledR}$ (partida 410S) e produzidos pelo Institute for Reference Materials and Measurements, IRMM (Bélgica). Como controle negativo para o gene da lectina foi utilizado DNA extraído de Escherichia coli.

A fim de certificar-se da não contaminação dos reagentes utilizados na extração de DNA e no preparo da solução de PCR, foram utilizados controles dos reagentes de extração (CRE) e controles dos reagentes da mistura de reação da PCR (CRM).

\subsection{Preparo da amostra}

O preparo da amostra é considerado um ponto crítico na metodologia utilizada, sendo uma etapa de grande importância na eficiência da extração de DNA. Todos os procedimentos devem ser realizados sob rigorosas condições de assepsia ambiental e dos equipamentos para evitar a contaminação acidental das amostras em análise. Foram pesados $1000 \mathrm{~g}$ da amostra, transferidos para sacos plásticos e homogeneizados manualmente por inversão cerca de 50 vezes.

\subsection{Extração de DNA}

Cem miligramas da amostra homogeneizada foram transferidos para microtubos de $1,5 \mathrm{ml}$ (em triplicata) e adicionados $1000 \mu \mathrm{l}$ de tampão composto por $20 \mathrm{~g} . \mathrm{L}^{-1}$ Brometo de Cetil Trimetil Amônio (CTAB); 0,1 M Tris-HCl; 1,4 M NaCl; 20 mM EDTA pH 8,0 (Tampão CTAB), e homo- geneizados. Após incubação a $65^{\circ} \mathrm{C}$ por 60 min em banho seco, com ocasional homogeneização por agitação, a suspensão foi centrifugada a $14000 \mathrm{~g}$ por $10 \mathrm{~min}$ e $500 \mu \mathrm{L}$ do sobrenadante foram misturados a $200 \mu \mathrm{L}$ de clorofórmio e centrifugados pelo mesmo tempo e velocidade anteriores. A fase superior foi transferida para outro tubo, misturada com o dobro de volume de solução de precipitação ( $5 \mathrm{~g} . \mathrm{L}^{-1} \mathrm{CTAB}$; 0,04 M NaCl) e incubada por 60 min em temperatura ambiente. Após centrifugação a $14000 \mathrm{~g}$ por $10 \mathrm{~min}$, o sobrenadante foi descartado e o precipitado dissolvido em $350 \mu \mathrm{l}$ de 1,2 M NaCl. Então, $350 \mu \mathrm{L}$ de clorofórmio foram adicionados, homogeneizados durante $30 \mathrm{~s}$ e centrifugados a $14000 \mathrm{~g}$ por $10 \mathrm{~min}$. A fase superior foi misturada com o mesmo volume de isopropanol gelado e deixado por aproximadamente $16 \mathrm{~h}$ a $-20^{\circ} \mathrm{C}$. Após centrifugação (10 min, $14000 \mathrm{~g} \mathrm{a} 4{ }^{\circ} \mathrm{C}$ ), o DNA precipitado foi ressuspenso em $50 \mu \mathrm{L}$ de água livre de DNase e RNase e estocado a $4{ }^{\circ} \mathrm{C}$ até ser utilizado (CARDARELLI et al., 2005). Foram extraídos pelo mesmo método $50 \mathrm{mg}$ do material de referência certificado e o DNA, ressuspenso em $100 \mu \mathrm{L}$ de água livre de DNase e RNase.

A presença e integridade do DNA extraído foram observadas utilizando-se corrida eletroforética de $90 \mathrm{~V}$ por $1 \mathrm{~h} 30 \mathrm{~min}$ em gel de agarose 0,7\% com brometo de etídeo $5 \mathrm{mg}^{\mathrm{mL}} \mathrm{m}^{-1}$, em tampão TBE $1 \mathrm{X}(100 \mathrm{mM}$ Tris $\mathrm{HCl}$; 90 mM ácido bórico; 1 mM EDTA pH 8,0). Foram aplicados no gel de agarose $5 \mu \mathrm{L}$ de DNA diluído à metade e $2 \mu \mathrm{L}$ de tampão de corrida (2,5 g.L $\mathrm{L}^{-1}$ azul de bromofenol; 2,5 g.L. $\mathrm{L}^{-1}$ xileno cianol; $300 \mathrm{~mL} . \mathrm{L}^{-1}$ glicerol; $20 \mathrm{mM}$ Tris $\mathrm{HCl} \mathrm{pH} \mathrm{8,0} \mathrm{qsp} 1 \mathrm{~L})$.

\subsection{Detecção de lectina}

Substâncias contidas no alimento, como proteínas, gorduras, polissacarídeos, polifenóis, açúcar caramelizado, entre outros, podem inibir a ação da DNA polimerase (AHMED, 2002). Por isso, é fundamental a utilização de controles da amplificação para evitar resultados falso-negativos. Esses controles avaliam a qualidade do DNA extraído e são representados por genes conservados de plastos ou genes específicos da soja como o gene le 1 da lectina de soja (HOLST-JENSEN et al., 2003). Os iniciadores utilizados para detectar o gene da lectina foram: GMO3 (5'GCCCTCTACTCCACCCCCATCC3') e GMO4 (5'GCCCATCTGCAAGCCTTTTTGTG3') (MEYER et al., 1996).

\subsection{Detecção de soja RR}

A identificação de soja RR foi realizada pela nested PCR, que consiste no uso de dois pares de iniciadores para um determinado evento de OGM. O primeiro par de iniciadores amplifica uma sequência específica do DNA alvo, que servirá de molde para o segundo par de 
iniciadores. Trata-se de um método que melhora a seletividade e sensibilidade da reação, permitindo que sejam detectados níveis abaixo de 0,1\% de OGM (MEYER e JACCAUD, 1997).

Os pares de iniciadores utilizados neste trabalho foram desenhados para amplificar especificamente fragmentos cobrindo a junção entre o promotor CaMV 35S, a sequência codificadora do peptídeo de endereçamento ao cloroplasto CTP e o gene codificador da CP4-EPSPS. Os iniciadores utilizados para identificar este gene foram: GMO09 (5'CATGAAGGACCGGYGGGAGAT3), GMO5 (5'CCACTGACGTAAGGGATGACG3'), GMO8 (5'TGGGGTTTATGGAAATTGGAA3') e GMO7 (5'ATCCCACTATCCTTCGCAA GA3') (MEYER E JACCAUD, 1997).

\subsection{Condições da PCR}

As reações de amplificação ocorreram em um volume final de $25 \mu \mathrm{L}$ contendo tampão de PCR 1 X ( $20 \mathrm{mM}$ Tris- $\mathrm{HCl}, \mathrm{pH} 8,4 ; 50 \mathrm{mM} \mathrm{KCl}) ; 1,5 \mathrm{mM} \mathrm{MgCl}, 0,16 \mathrm{mM}$ de cada dNTP; 0,24 $\mu \mathrm{M}$ de cada iniciador; 1 unidade de TaqDNA polymerase; e $2 \mu \mathrm{l}$ de DNA. As amplificações foram realizadas em termociclador "GeneAmp PCR System 2400 - Applied Biosystems" com os seguintes programas: ciclo OGM-lectina para os iniciadores OGM3/ OGM4: desnaturação inicial a $95^{\circ} \mathrm{C}$ por 3 min seguida de 40 ciclos de $95^{\circ} \mathrm{C}$ por $30 \mathrm{~s}, 63^{\circ} \mathrm{C}$ por $30 \mathrm{~s}$, e $72{ }^{\circ} \mathrm{C}$ por $30 \mathrm{~s}$, extensão final a $72{ }^{\circ} \mathrm{C}$ por $3 \mathrm{~min}$; ciclo nested. soja 1 para os iniciadores GMO5/GMO9: desnaturação inicial a $95^{\circ} \mathrm{C}$ por 3 min seguida de 25 ciclos de $95^{\circ} \mathrm{C}$ por $30 \mathrm{~s}, 60^{\circ} \mathrm{C}$ por $30 \mathrm{~s}$, e $72^{\circ} \mathrm{C}$ por $40 \mathrm{~s}$; extensão final a $72^{\circ} \mathrm{C}$ por $3 \mathrm{~min}$. Após amplificação com os iniciadores GMO5/GMO9, $1 \mu \mathrm{L}$ do produto da PCR foi utilizado como molde na nested PCR com os iniciadores GMO7/GMO8 e as mesmas condições de reação por 35 ciclos.

Os produtos da PCR $(12 \mu \mathrm{L}$ da reação $+2 \mu \mathrm{L}$ do tampão corrida) foram separados por eletroforese a $80 \mathrm{~V}$ por 30 min seguidos por $100 \mathrm{~V}$ por $1 \mathrm{~h} 30 \mathrm{~min}$ em gel de agarose 2\% com tampão TBE 1X e corado com brometo de etídeo. A visualização ocorreu em transluminador UV e as imagens foram fotografadas no analisador de imagens "ImageMaster - VDS - Pharmacia Biotech".

\subsection{Quantificação de OGM por PCR em tempo real}

A análise de quantificação de OGM foi realizada utilizando o sistema $\operatorname{TaqMan}^{\circledR}$ baseado na atividade exonucleásica $5^{\prime} \rightarrow 3^{\prime}$ da TaqDNA polimerase para produzir um sinal fluorescente. A emissão foi medida pelo equipamento Sequence Detection System ABI-Prism 7500, também denominado Real Time Detection System da Applied Biosystems. Foi utilizado o kit $\operatorname{TaqMan}^{\oplus} \mathrm{GMO}$ 35S Soy, que tem como alvos os genes da lectina e do promotor 35S derivado do CaMV em reação de PCR multiplex. O kit contém, além dos constituintes da PCR convencional, sondas marcadas com corantes fluorescentes para os dois alvos (VAïTILINGOM et al., 1999).

As reações de amplificação ocorreram em um volume final de $25 \mu \mathrm{L}$ : $22 \mu \mathrm{L}$ de "TaqMan GMO 35S Soy PCR Mix", 0,5 $\mu$ l de "AmpliTaq Gold DNA Polimerase" e 2,5 $\mu \mathrm{L}$ de DNA ou do controle positivo ou negativo. Os parâmetros de termociclagem foram: desnaturação a $94{ }^{\circ} \mathrm{C}$ por 9 min seguida de 45 ciclos de $95{ }^{\circ} \mathrm{C}$ por $20 \mathrm{~s}$ e $60^{\circ} \mathrm{C}$ durante $60 \mathrm{~s}$. A análise de quantificação pela PCR em tempo real foi realizada em todas as amostras que, após análise qualitativa, mostraram-se positivas para presença de soja geneticamente modificada em sua composição.

O cálculo das concentrações de soja GM nos alimentos foi realizado com o programa GMO analysis macro v1.7.2 desenvolvido pela Applied Biosystems, utilizando-se a curva de calibração obtida com diferentes concentrações do MRC.

\section{Resultados e discussão}

Foram analisadas 16 amostras de "farinha de trigo" de 10 diferentes marcas e 8 amostras de produtos identificados como "preparados à base de trigo" de 7 diferentes marcas, totalizando um universo de 24 amostras.

\subsection{Extração do DNA}

O preparo da amostra é um dos fatores que influencia na eficiência da extração de DNA. Aspectos da amostra como dimensão, estado físico, composição devem ser observados, sendo o conhecimento sobre o processamento do alimento de caráter fundamental.

A extração de DNA utilizando tampão CTAB mostrou-se eficiente para as duas categorias de produtos analisados, sendo uma boa escolha para análise de rotina por ser uma técnica simples, de baixo custo e segura.

\subsection{Detecção de lectina e de soja $\mathbf{R R}^{\circledR}$}

Os géis de agarose obtidos após a eletroforese dos produtos de amplificação pela PCR do gene le1, específico da lectina, e pela nested PCR do gene CP4 EPSPS oriundo do DNA genômico extraído de farinha de trigo e preparados à base de farinha de trigo estão representados nas Figuras 2 e 3.

A identificação de genes específicos de soja nas amostras de alimentos foi realizada pela técnica da PCR utilizando os iniciadores GMO3/GMO4 que amplificam um fragmento de $118 \mathrm{pb}$ do gene da lectina.

As amostras denominadas "preparados à base de farinha de trigo" (misturas para bolinhos de chuva, para quiches e para panquecas) apresentaram resultados $100 \%$ positivos para o gene da lectina, que evidencia 
Soja geneticamente modificada em alimentos contendo farinha e preparados à base de farinha de trigo. Detecção e adequação à legislação de rotulagem

FERREIRA, R. T. B. et al.

presença de soja nestes produtos. O gene da lectina foi encontrado em $94 \%$ das amostras de farinha de trigo de nove diferentes marcas. Ressalta-se que não havia declaração de derivados de soja nos rótulos destes produtos. Em apenas uma marca de farinha de trigo não foram detectados genes da lectina ou da soja $R^{\circledR}{ }^{\circledR}$.

Todas as amostras positivas para o gene da lectina foram analisadas para a detecção de genes de soja $R^{\circledR}{ }^{\circledR}$. A reação de nested PCR utilizando os iniciadores GMO5/GMO9 e GM07/GMO8 foi realizada para confirmar a presença do fragmento de 169 pb específico da soja $\mathrm{RR}^{\circledR}$ (Figura 3a e 3b).

A vantagem da identificação por nested PCR é a elevada especificidade, pois, uma vez que ocorra a amplificação de um fragmento falso-positivo pelo primeiro par de iniciadores, a probabilidade de sequências específicas serem amplificadas é muito baixa.

\subsection{Quantificação de soja GM}

Neste trabalho utilizou-se a tecnologia do Real Time PCR por ser um método quantitativo confiável, um pré-requisito essencial para a aplicação das diretivas de rotulagem. Esta tecnologia permite o monitoramento da fluorescência associado ao produto de amplificação durante todo o processo da PCR, avaliada com diferentes tipos de fluoróforos com comprimentos de onda específicos, tornando possível ensaios multiplex.

A quantificação por PCR em Tempo Real demonstrou que $75 \%$ (12/16) das amostras de farinha de trigo e $100 \%$ dos preparados à base de farinha de trigo para alimentação humana continham teores acima de 1\% de OGM e deveriam, portanto, apresentar no rótulo o símbolo estabelecido pela Portaria $n^{\circ} 2658$, de 22 de dezembro de 2003, por apresentarem teores acima de 1\% (BRASIL, 2003b). Três "preparados à base de farinha de trigo" da mesma marca das farinhas de trigo apresentaram resultados iguais entre si (Tabela 1 ).

\subsection{Análise da rotulagem}

A Instrução normativa $n^{\circ} 8$, de 2 de junho de 2005, define as características de identidade e qualidade da farinha de trigo, aplicável à farinha de trigo

(a)
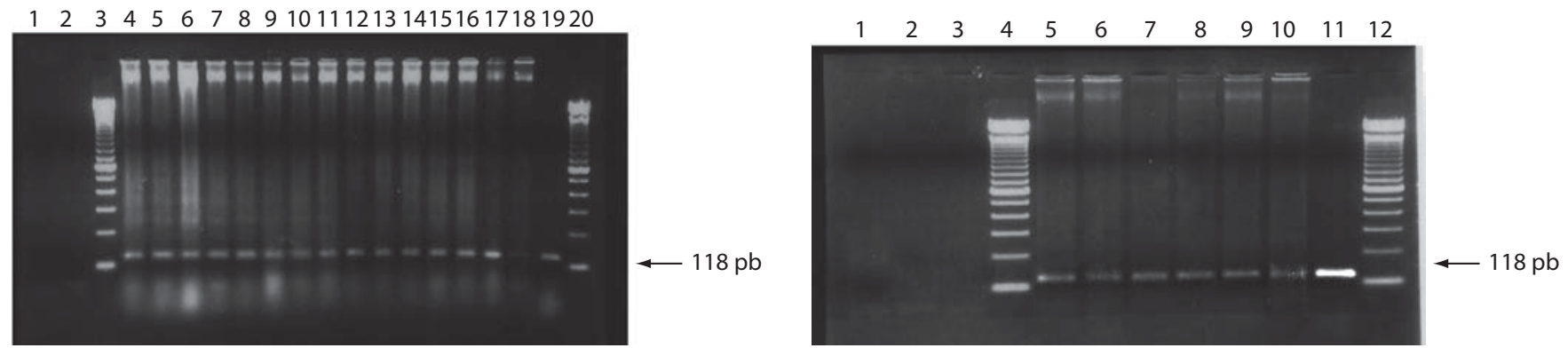

Figura 2. Eletroforese em gel de agarose da amplificação pela PCR do gene le1, específico da lectina (118pb), oriundo das amostras de alimentos analisadas. A seta indica o peso molecular esperado: a) amostras de farinha de trigo - 1: CRM; 2: Padrão 0\% Soja RR ${ }^{\circledR}$; 3 e 20: 100 bp Ladder; 4-18: Farinhas ; 19: Padrão 2\% Soja RR ${ }^{\circledR}$; b) amostras de preparados à base de farinha de trigo - 1: CRE; 2: CRM; 3 : Padrão 0\% Soja RR ${ }^{\circledR} ; 4$ e 12: 100 bp Ladder; 5 - 10: Preparados; 11:Padrão 2\% Soja RR ${ }^{\circledR}$.

(a)

(b)
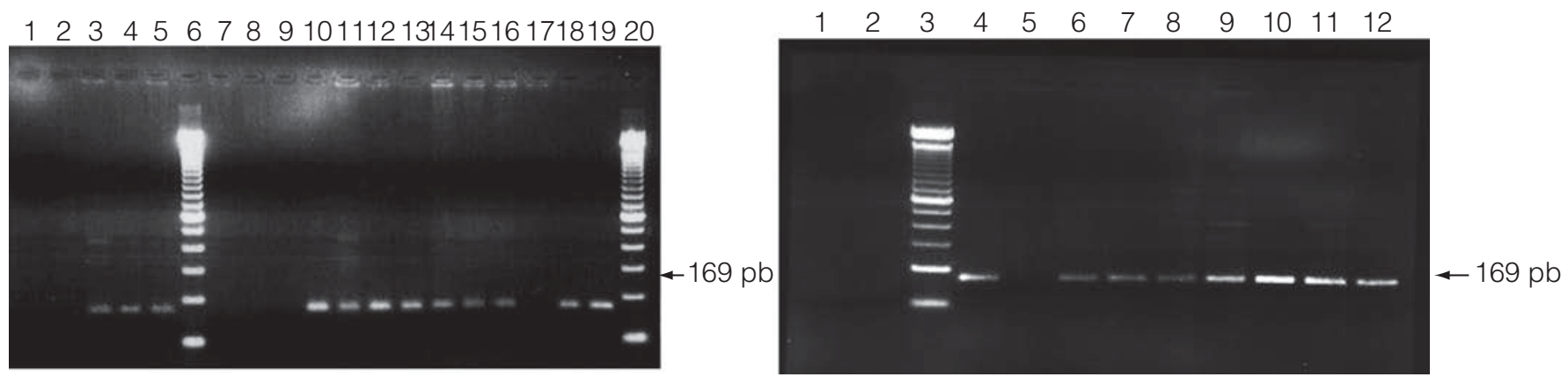

Figura 3. Eletroforese em gel de agarose da amplificação pela nested PCR do gene CP4 EPSPS, específico da soja RR ${ }^{\circledR}$ (169 pb), oriundo das amostras de alimentos analisadas. A seta indica o peso molecular esperado: a) Amostras de farinha de trigo - 1: CRM; 2: Padrão 0\% Soja RR ${ }^{\oplus}$; 3-5 e 7-18: Farinhas; 6 e 20: 100 bp Ladder; 19: Padrão 2\% Soja RR ${ }^{\circledR}$; b) Amostras de preparados à base de farinha de trigo - 1: CRM; 2: Padrão 0\% Soja RR ${ }^{\circledR}$;: 100 bp Ladder; 4 - 11: Preparados; 12: Padrão 2\% Soja RR ${ }^{\circledR}$ 
Tabela 1. Amplificação, identificação e quantificação das amostras analisadas.

\begin{tabular}{|c|c|c|c|}
\hline Amostra $\left(\mathbf{N}^{\circ}\right)$ & Lectina positivo & Soja $\mathbf{R R}^{\circledR}$ positivo & Soja $\mathbf{R R}^{\circledR}$ acima de $1 \%$ \\
\hline Farinha de Trigo (14) & 13 & 12 & 12 \\
\hline Farinha de Trigo Integral (2) & 2 & 0 & 0 \\
\hline Mistura para bolo (5) & 5 & 5 & 5 \\
\hline Mistura para quiche (1) & 1 & 1 & 1 \\
\hline Mistura para panqueca (1) & 1 & 1 & 1 \\
\hline Mistura para bolinho de chuva (1) & 1 & 1 & 1 \\
\hline Total (24) & 23 & 20 & 20 \\
\hline
\end{tabular}

orgânica, não orgânica e àquela que for proveniente de trigo geneticamente modificado e conceitua farinha de trigo como o produto elaborado com grãos de trigo (Triticum aestivum L.) ou outras espécies de trigo do gênero Triticum, ou combinações por meio de trituração ou moagem e outras tecnologias ou processos. Para farinha de trigo adicionada de outros vegetais, a denominação de venda deve estar identificada na rotulagem de forma clara com a expressão "Farinha de trigo com + o nome comum da espécie adicionada". No entanto, este dispositivo legal não determina o percentual permitido da espécie vegetal adicionada a ela. $\mathrm{O}$ item 4 do mesmo documento referente aos "requisitos gerais" estabelece a não permissão da comercialização de farinha de trigo que apresentar características macroscópicas, microscópicas, microbiológicas e substâncias nocivas à saúde acima dos limites estabelecidos por legislação específica vigente (BRASIL, 2005).

A farinha integral de soja é um produto obtido diretamente dos grãos de soja. O tratamento térmico é uma etapa do seu processamento, mas quando a farinha de soja é utilizada para branqueamento de farinha de trigo destinada à fabricação de pães não deve ocorrer o tratamento térmico, já que as enzimas presentes na soja devem permanecer ativas até o final do tratamento da farinha de trigo.

Na Portaria $n^{\circ} 354$ de 18 de julho de 1996 (revogada) o uso de farinha de soja enzimaticamente ativa até um máximo de $1 \%$ era permitida, como ingrediente opcional, justificado pelo processo de branqueamento da farinha de trigo. Na Instrução Normativa vigente (I.N. $n^{\circ}$ 08, de 02/06/2005) não há menção da farinha de soja enzimaticamente ativa como ingrediente, porém permite o uso de soja, desde que seja declarada no rótulo, como também permite o uso de trigo transgênico ainda não liberado nacionalmente nem para plantio nem para comercialização. As duas amostras de farinha de trigo integral analisadas continham soja apesar de não terem sofrido tratamento enzimático.

A qualidade do produto não se restringe apenas às características intrínsecas do produto, mas é entendida como um binômio indissociável, em cuja avaliação as variáveis eficácia e segurança devem estar sempre presentes.

Como se trata de um grão de custo menor do que a do trigo, a soja pode estar sendo utilizada para adulterar o trigo como ingrediente de menor valor. Muitas vezes, o trigo é utilizado como cultura de rotação, principalmente com a soja, devido ao fato da soja ser uma cultura de verão e o trigo uma cultura de inverno (CAMARGO et al., 2004), podendo causar contaminação de soja em produtos com trigo. A segregação de diferentes grãos desde o plantio ao processamento do alimento poderia minimizar este problema.

Um aspecto fundamental na análise de alimentos geneticamente modificados é a quantificação, uma vez que o limite máximo (1\%) de OGM em alimentos é a base para rotulagem no Brasil. A detecção de OGM no controle de matérias-primas é um aspecto importante para a indústria de alimentos.

Todas as amostras de "preparados à base de farinha de trigo" analisadas apresentaram resultado positivo para soja $R^{\circledR}{ }^{\circledR}$. Das amostras positivas para soja $\mathrm{RR}^{\circledR}$ quantificadas, todas necessitavam de rotulagem por estarem acima de $1 \%$.

Considera-se, portanto, que farinhas de trigo contendo soja $\mathrm{RR}^{\circledR}$ estão sendo utilizadas como matérias-primas para fabricação de produtos, sem monitoramento.

Doenças alérgicas representam um problema de saúde pública, atingindo mais de $20 \%$ da população. As alergias alimentares podem afetar até $2 \%$ da população adulta e até $8 \%$ de crianças. Em um indivíduo sensibilizado, a ingestão regular de pequenas quantidades de alérgenos, pode provocar distúrbios digestivos e respiratórios, como rinite e asma, e reações na pele como urticária e dermatite atópica. Para alguns indivíduos alérgicos, o contato com certos alérgenos alimentares pode representar até mesmo risco de morte por choque anafilático. Indivíduos sensíveis podem também estar expostos inadvertidamente a proteínas pelo consumo de produtos alimentícios supostamente livres de certos alérgenos. Produtos alimentícios podem ser contaminados com constituintes alimentares estranhos durante a fase de 
Soja geneticamente modificada em alimentos contendo farinha e preparados à base de farinha de trigo. Detecção e adequação à legislação de rotulagem

FERREIRA, R. T. B. et al.

processamento, resultante de higienização inadequada dos equipamentos ou do reuso de produtos contendo alérgenos, ou ainda no transporte e estocagem (POMS et al., 2004). A soja faz parte do grupo de alimentos com registro de casos de alergia, sendo a recomendação médica básica evitar o consumo desses alimentos por pessoas alérgicas (GAZZONI, 2005 e ASBAI, 2005). A FAO (Food and Agriculture Organization of the United Nations) inclui a soja entre os 8 alérgenos alimentares mais significativos (CORDLE, 2004). A escolha dos alimentos feita pelo consumidor é realizada essencialmente pela rotulagem. Uma vez que farinhas de trigo e produtos à base de farinha de trigo estão apresentando soja em sua composição sem nenhuma informação nos rótulos, o consumo desses produtos poderá ocasionar malefícios à saúde de pessoas alérgicas à soja.

A rotulagem de alimentos é o principal meio de comunicação entre o produtor e o consumidor. Existe uma preocupação com a segurança do consumidor tendo em vista a diversidade de produtos que vêm sendo desenvolvidos pela indústria de alimentos.

Ainda é preciso reconhecer que a importância da rotulagem não se verifica apenas na garantia do direito do consumidor em ser plenamente informado sobre o produto que está adquirindo ou ainda à segurança do alimento transgênico, até porque a sua liberação para o consumo depende de prévia análise de riscos e da aprovação dos testes procedidos pela Vigilância Sanitária, sendo o processo de rotulagem um instrumento eficaz de uma política de prevenção para se detectar os efeitos adversos de longo prazo e com isso se corrigir eventos não previstos nos testes realizados antes da liberação comercial.

A autenticidade dos alimentos torna-se um objetivo a ser alcançado. Por isso, é cada vez mais importante detectar a introdução no mercado de produtos fraudulentamente rotulados e de qualidade inferior, quer por razões econômicas quer por razões de saúde pública.

$O$ decreto $n^{\circ} 4680$ de 24/04/03 obriga a rotulagem de alimentos e ingredientes que contenham ou sejam produzidos a partir de OGM com presença acima de $1 \%$ e a Portaria $n^{\circ} 2658$ de 22/12/03 define o símbolo que deve constar nos produtos que estejam inclusos nesta categoria.

Dentre todas as amostras analisadas, apenas uma amostra de farinha de trigo apresentou resultado negativo para presença de soja, porém nenhuma das amostras analisadas possui declaração da soja como ingrediente em seus rótulos.

Straub et al. (1999) estudaram o limite de detecção para soja geneticamente modificada na produção de "massas" de trigo e verificaram que alimentos presentes no mercado alemão contendo soja geneticamente modi- ficada poderiam necessitar de rotulagem. Porém, no Brasil, nenhuma avaliação ainda havia sido realizada com estes produtos.

A partir dos resultados da quantificação de soja geneticamente modificada presente nestes alimentos pela técnica da PCR em tempo real, uma discussão ampla sobre a rotulagem de produtos de trigo faz-se necessária para assegurar os direitos do consumidor, cumprindo as determinações legais.

\section{Conclusões}

A presença de soja foi observada em 94\% dos alimentos analisados neste trabalho. O uso da soja $\mathrm{RR}^{\circledR}$ foi detectado em 75\% (12/16) das farinhas de trigo e 100\% dos preparados à base de farinha de trigo, verificando-se assim a não aplicação da legislação de rotulagem nestes produtos, omitindo-se esta informação do consumidor.

\section{Referências}

ABITRIGO - Associação Brasileira da Indústria do Trigo. O valor nutricional do trigo. Disponível em: < www.abitrigo.com.br>. Acesso em: 08 Outubro 2006.

AHMED, F. E. Detection of genetically modified organisms in foods. Trends In Biotechnology, London, v. 20, n. 5, p. 215-223, 2002.

ARAÚJO, W. M. C.; CIACCO, C. F.; ESTEVES, W.; CAMARGO, C. R. de O. Efeito da adição de farinha de soja desengordurada na massa de farinha de trigo. Ciência e Tecnologia de Alimentos, Campinas, v.16, n.1, p. 26-31, 1996.

ASBAI - Associação Brasileira de Alergia e Imunopatologia. Alergia Alimentar. Disponível em: <http://www.sbai.org.br>>. Acesso em: 11 Novembro 2005.

BRASIL. Ministério da Agricultura, Pecuária e Abastecimento. Instrução Normativa $n^{\circ}$ 08, de 02 de junho de 2005. Aprova o regulamento técnico de identidade e qualidade da farinha de trigo. Diário Oficial [da] República Federativa do Brasil, Brasília, DF, 03 junho 2005.

BRASIL. Ministério da Ciência e Tecnologia. Decreto $n^{\circ} 4.680$, de 24 de abril de 2003. Regulamenta o direito à informação quanto aos alimentos e ingredientes alimentares destinados ao consumo humano ou animal que contenham ou sejam produzidos a partir de organismos geneticamente modificados.

Diário Oficial da União [da] República Federativa do Brasil, Brasília, DF, 24 abril 2003a.

BRASIL. Ministério da Justiça. Portaria $n^{\circ} 2658$, de 22 de dezembro de 2003. Regulamenta o emprego do símbolo no rótulo dos produtos transgênicos. Diário Oficial [da] República Federativa do Brasil, Brasília, DF, 26 dezembro 2003b.

BRASIL. Ministério da Saúde. Agência Nacional de Vigilância Sanitária - ANVISA. Portaria n 354, de 18 de julho de 1996. Regulamenta a norma técnica referente à farinha de trigo. 
Soja geneticamente modificada em alimentos contendo farinha e preparados à base de farinha de trigo. Detecção e adequação à legislação de rotulagem

FERREIRA, R. T. B. et al.

Diário Oficial [da] República Federativa do Brasil, Brasília, DF, 22 julho 1996

BRASIL. Ministério da Saúde. Agência Nacional de Vigilância Sanitária - ANVISA. Resolução RDC n ${ }^{\circ} 259$, de 20 de setembro de 2002. Regulamento técnico sobre rotulagem de alimentos embalados. Diário Oficial [da] República Federativa do Brasil, Brasília, DF, 23 setembro 2002

CAMARGO, C. E. O.; FERREIRA-FILHO, A. W. P.; SALOMON, M. V. Temperature and $\mathrm{pH}$ of the nutrient solution on wheat primary root growth. Scientia Agrícola, Piracicaba, v. 61, n. 3, p. 313-318, 2004

CARDARELLI, P.; BRANQUINHO, M. R.; FERREIRA, R. T. B.; CRUZ, F. P.; GEMAL, A. L. Detection of GMO in food products in Brazil: the INCQS experience. Food Control, Reading, v. 16, n. 10, p. 859-866, 2005.

CONAB - Companhia Nacional de Abastecimento. Balanço de oferta e demanda. Avaliação da safra agrícola 2006/2007. Terceiro levantamento - dezembro/2006. Disponível em: <www.conab.gov.br>. Acesso em: 10 Dezembro 2006.

CORDLE, C. T. Soy protein allergy: incidence and relative severity. The Journal of Nutrition, Columbus, v. 135, n. 5, p. 1213S-1219S, 2004.

COSTA, M. G.; SOUZA, E. L.; STAMFORD, T. L. M.; ANDRADE, S. A. C. Qualidade tecnológica de grãos e farinhas de trigo nacionais e importados. Ciência e Tecnologia de Alimentos, Campinas, v. 28, n. 1, p. 220-225, 2008.

GAZZONI, D. L. Soja e alergia. Disponível em: <http://agrolink. com.br>. Acesso em: 27 Maio 2005.

HOLST-JENSEN, A.; RONNING, S. B.; LOVSETH, A.; BERDAL, K. G. PCR technology for screening and quantification of genetically modified organisms (OGM). Analytical and Bioanalytical Chemistry, Heidelberg, v. 375, n. 8, p. 985-993, 2003.

INMETRO - Instituto Nacional de Metrologia, Normalização e Qualidade Industrial. Farinha de trigo especial. Disponível em: <http://www.inmetro.gov.br/ consumidor/produtos/farinha. asp> Acesso em : 11 Abril 2005.

JANKIEWICZ, A.; BROLL, H.; ZANGON, J. The official method for the detection of genetically modified soybeans (German Food Act LMBG 35): a semi-quantitative study of sensitivity limits with glyphosate-tolerant soybeans (Roundup Ready) and insectresistant Bt maize (maximizer). European Food Research and Technology, Heidelberg, v. 209, n. 2, p. 77-82, 1999.

MEYER, R.; JACCAUD, E. Detection of genetically modified soya in processed food products: development and validation of a PCR assay for the specific detection of GlyphosateTolerant Soybeans. In: EUROPEAN CONFERENCE ON FOOD CHEMISTRY, 9, 1997, Interlaken. Proceedings... Interlaken: R. Amado, R. Barraglia, 1997, v. 1, p. 23-28. (Autenticity and adulteration of food - The analytical approach).

MEYER, R.; CHARDONNENS, F.; HÜBNER, P.; LÜTHY, J. Polymerase chain reaction (PCR) in the quality and safety assurance of food: detection of soya in processed meat products. Zeitschrift fiir Lebensmittel - Untersuschung und - Forschung A, Heidelberg, v. 203, n. 4, p. 339-344, 1996.

POMS, R. E.; ANKLAM, E.; KUHN, M. Polymerase Chain Reaction Techniques for food allergen detection. Journal of AOAC International, Gaithersburg, v. 87, n. 6, p. 1391- 1397, 2004.

RIBOTTA, P. D.; SEBASTIÁN, A. A.; LEÓN, A .E.; AÑON, M. C. Effect of soybean addition on the rheological properties and breamaking quality of wheat flour. Journal of the Science of Food and Agriculture, Hoboken, v. 85, n. 11, p. 1889-1896, 2005.

SINGER, C. S. Propriedades físico-químicas, reológicas, entálpicas e de panificação da farinha obtida de trigo irradiado. São Paulo, 2006. 97 f. Dissertação (Mestrado em Engenharia) - Escola Politécnica da Universidade de São Paulo, Universidade de São Paulo.

SOARES, C. A.; CAMPOS, J. M. S.; FILHO, S. C. V.; VALADARES, R. F. D.; MENDONÇA, S. S.; QUEIROZ, A.; LANA, R. P. Consumo, digestibilidade aparente, produção e composição do leite de vacas leiteiras alimentadas com farelo de trigo. Revista Brasileira de Zootecnia, Viçosa, v. 33, n. 6, p. 2161-2169, 2004.

StRAUB, J. A.; HERTEL, C.; HAMMES, W. P. Limits of a PCR-based detection method for genetically modified soya beans in wheat bread production. Zeitschrift fiir Lebensmittel - Untersuschung und - Forschung A, Heidelberg, v. 208, n. 2, p. 77-82, 1999.

VAÏTILINGOM, M.; PIJNENBURG, H.; GENDRE, F.; BRIGNON, P. Real-time Quantitative PCR Detection of Genetically Modified Maximizer Maize and Roundup Ready Soybean in Some Representative Foods. Journal of Agricultural and Food Chemistry, Washington, v. 47, n. 12, p. 5261-5266, 1999.

ZIMMERMANN, A.; LÜTHY, J.; PAULI, U. Quantitative and qualitative evaluation of nine different extraction methods for nucleic acids on soya bean food samples. Zeitschrift fiir Lebensmittel - Untersuschung und - Forschung A, Heidelberg, v. 207, n. 2 , p. 81-90, 1998. 